\title{
Korelasi IgE terhadap rasio neutrofil/eosinofil jaringan dan darah penderita rinosinusitis kronik Aspergillus fumigatus
}

\author{
Fifin Pradina Duhitatrissari, Endang Retnoningsih, Iriana Maharani \\ Departemen Ilmu Kesehatan Telinga Hidung Tenggorok-Bedah Kepala Leher \\ Fakultas Kedokteran Universitas Brawijaya/Rumah Sakit Dr. Saiful Anwar \\ Malang
}

\begin{abstract}
ABSTRAK
Latar Belakang: Prevalensi rinosinusitis kronik (RSK) jamur saat ini cenderung meningkat. Jamur berperan sebagai mikroorganisme dan merupakan salah satu penyebab RSK. Pemeriksaan immunoglobulin $\mathrm{E}$ (IgE) Aspergillus fumigatus (Af) digunakan untuk menegakkan diagnosis rinosinusitis jamur tanpa harus melalui tindakan invasif. Perubahan rasio neutrofil/eosinofil (RNE) digunakan untuk memahami respon inflamasinya. Tujuan: Mengetahui korelasi antara kadar IgE Af terhadap perubahan RNE mukosa dan darah pada penderita RSK jamur. Metode: Penelitian cross sectional, melibatkan 13 subjek penelitian dengan pengambilan darah dan mukosa sinus maksila untuk diidentifikasi Af dengan Polymerase Chain Reaction (PCR), dilanjutkan ELISA untuk mengukur kadar IgE Af serta flowcytometry untuk mengukur kadar neutrofil dan eosinofil mukosa sinus maksila dan darah. Hasil: Rerata IgE Af mukosa 1,112 $\pm 0,883$ $\mathrm{kU} / \mathrm{mL}$, darah $1,041 \pm 0,876 \mathrm{kU} / \mathrm{mL}(\mathrm{N}<0,35 \mathrm{kU} / \mathrm{L})$. Dengan uji T berpasangan didapatkan kesesuaian antara

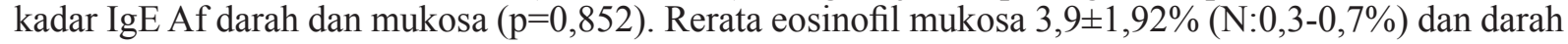
4,88 $\pm 2,02 \%$ (N:3-9\%). Rerata neutrofil mukosa 4,28 $\pm 2,04$ (N:1,1-1,7\%) dan darah 49,41 $\pm 13,98 \%$ (N:55,8$59,6 \%$ ). Rerata RNE mukosa 1,77 $\pm 2,28$ (N:2,8). Rerata RNE darah 12,12 $\pm 6,25$ (N:9,6). Didapatkan 93,3\% mukosa subjek penelitian mengalami inflamasi eosinofilik, 53,3\% mengalami inflamasi eosinofilik pada darah. Dengan uji T berpasangan terdapat ketidaksesuaian RNE mukosa dengan darah (p:0,000). Tes korelasi Pearson antara IgE Af dengan RNE mukosa, tidak terdapat korelasi bermakna (p:0,523) dan antara IgE Af dengan RNE darah, tidak terdapat korelasi bermakna (p:0,607). Kesimpulan: Terdapat kesesuaian antara kadar IgE Af mukosa dan darah, tetapi tidak terdapat kesesuaian antara RNE mukosa dan darah. Tidak terdapat korelasi antara peningkatan kadar IgE Af dengan RNE pada mukosa dan darah.
\end{abstract}

Kata kunci: rinosinusitis kronik jamur, IgE Aspergillus fumigatus, rasio neutrofil/eosinofil

\begin{abstract}
Background: The prevalence of chronic fungal rhinosinusitis (CFR) nowadays tends to increase. Fungi act as microorganisms and is one of the causes of chronic rhinosinusitis. The examination of immunoglobulin E (IgE) Aspergillus fumigatus (Af) is applied to establish the diagnosis of CFR without having to do invasive actions. Neutrophil/eosinophil ratio (NER) changes are used to understand the inflammatory response. Purpose: To determine the correlation between IgE Af levels on changes of mucosal and blood NER in CFR patients. Method: A cross-sectional study, involving 13 subjects by taking sample of the blood and maxillary sinus mucosa to identify Af with Polymerase Chain Reaction (PCR), followed by ELISA to measure the levels of IgE Af, and flowcytometry to measure the levels of neutrophils and eosinophils of the blood and mucosa of maxillary sinuses. Results: The mean IgE of mucosa: $1.112 \pm 0.883 \mathrm{kU} / \mathrm{mL}$, and of blood: $1.041 \pm 0.876 \mathrm{kU} / \mathrm{mL}(\mathrm{N}<0.35 \mathrm{kU} / \mathrm{L})$. With paired T-test, there was a match between blood and mucosal IgE level ( $p=0.852)$. The mean eosinophil of mucosa: $3.9 \pm 1.92 \%,(\mathrm{~N}: 0.3-0.7 \%)$ and of blood $4.88 \pm 2.02 \%$ (N:3-9\%). The mean neutrophil of mucosa: $4.28 \pm 2.04 \%(N: 1.1-1.7 \%)$ and of blood $49.41 \pm 13.98 \%(N: 55.8-59.6 \%)$. The mean NER of mucosa: $1.77 \pm 2.28(\mathrm{~N}: 2.8)$, and of blood: $12.12 \pm 6.25(\mathrm{~N}: 9.6)$. It was revealed that $93.3 \%$ of mucosal subjects had eosinophilic inflammation, $53.3 \%$ had eosinophilic inflammation in blood. With paired T-test there was a mucosal NER mismatch with blood (p:0.000). The Pearson correlation-test between IgE Af and NER mucosa had no significant correlation (p:0.523), and between IgE Af with NER of blood there was no
\end{abstract}


significant correlation (p:0.607). Conclusion: There was a correspondence between IgE Af of mucosa and blood levels, but there was no match between the mucosal and blood NERs. There was no correlation between elevated levels of IgE Af and NER in the mucosa and blood.

Keyword: chronic fungal rhinosinusitis, IgE Aspergillus fumigatus, neutrophil/eosinophil ratio

Alamat Korespondensi: Dr. Fifin Pradina Duhitatrissari. Departemen Ilmu Kesehatan Telinga Hidung Tenggorok-Bedah Kepala dan Leher Fakultas Kedokteran Universitas Brawijaya/ Rumah Sakit Dr. Saiful Anwar Malang. Email: fifin_chesta@yahoo.com.

\section{PENDAHULUAN}

Rinosinusitis maksila kronik adalah infeksi mukosa dan/atau jaringan submukosa sinus maksila yang berlangsung selama $\geq 12$ minggu. Rinosinusitis kronik (RSK) merupakan proses inflamasi mukosa hidung dan sinus paranasal dengan prevalensi tinggi yang menjadi masalah kesehatan global. Permasalahan yang disebabkan oleh RSK dapat menyebabkan beban ekonomi yang tinggi dan berdampak pada penurunan kualitas hidup, produktivitas kerja, daya konsentrasi bekerja dan belajar. ${ }^{1}$

Rinosinusitis merupakan masalah kesehatan yang umum ditemui. Di Amerika Serikat prevalensi RSK pada dewasa mencapai 14\%-16\%. ${ }^{1}$ Dari data tahun 2014 di Rumah Sakit dr. Saiful Anwar Malang, RSK menduduki peringkat ke tujuh penyakit terbanyak di Poli Telinga Hidung TenggorokBedah Kepala Leher(THT-KL) dengan jumlah 592 penderita $(25,4 \%){ }^{2}$ Penyebab RSK bersifat multifaktorial, termasuk di dalamnya peran mikroorganisme (bakteri dan jamur), inflamasi akibat alergi maupun non alergi, serta berbagai penyebab non-mikroorganisme dan non-imunologik. Penyebab utama dan terpenting adalah obstruksi ostium sinus. ${ }^{2,3}$

Maharani $\mathrm{dkk}^{2}$ melaporkan bahwa seluruh penderita RSK (29 orang) yang ikut dalam penelitian di Rumah Sakit dr. Saiful Anwar Malang, ditemukan jamur dengan pemeriksaan polymerase chain reaction (PCR) dari sampel cairan bilasan sinus maksila. Di Iran didapat sebesar 25,8\% (16 pasien dari 62 pasien RSK) menderita rinosinusitis akibat jamur. ${ }^{4}$
Peran jamur pada rinosinusitis sampai saat ini masih merupakan kontroversi dan telah menjadi bahan perdebatan selama beberapa dekade. ${ }^{5}$ Banyak penelitian menunjukkan kemungkinan adanya peranan jamur dalam kejadian RSK. ${ }^{3,5}$ Jamur bisa berperan sebagai mikroorganisme dan sebagai alergen. Jamur sebagai mikroorganisme akan melalui alur $\beta$-glucan dandectin-1, serta terkait dengan peningkatan Immunoglobulin $\mathrm{G}$ (IgG) Aspergillus fumigatus yang berhubungan dengan infeksi kronik dan berulang pada sistem pernapasan yang kemudian mengakibatkan peningkatan neutrofil, sehingga terjadi kerusakan mukosa sinus paranasal. Jamur sebagai alergen alur yang dilalui adalah sebagai reaksi hipersensitivitas tipe 1, yang berkaitan dengan peningkatan Imunoglobulin E (IgE) Aspergillus fumigatus yang mengakibatkan peningkatan eosinofil dan menyebabkan kerusakan mukosa sinus paranasal. ${ }^{2,4-6}$

Rinosinusitis jamur dibagi menjadi dua kelompok besar, yaitu rinosinusitis jamur invasif dan non-invasif. ${ }^{5}$ Jamur yang paling banyak menyebabkan penyakit pada manusia adalah Aspergillus fumigatus dan Mucor sp. ${ }^{5}$ Aspergillus spp. dan beberapa genus jamur lainnya memiliki $\beta$-glucan yang merupakan suatu polimer glukosa atau polisakarida pada bagian dalam dinding sel jamur yang berperan dalam aktivasi leukosit, stimulasi respon fagositosis dan sitotoksis, dan produksi oksigen reaktif dan nitrogen. $\beta$-glucan diteliti sebagai penanda beberapa infeksi jamur dan sebagai imunomodulator pada kadar tertentu. Agar peran sebagai imunomodulator dapat dicapai, dibutuhkan 
peran reseptor pada tubuh pejamu untuk dapat mengenali $\beta$-glucan, dan peran tersebut dijalankan oleh dectin-1., ${ }^{4,5}$

Pada pasien RSK alergi jamur, mukosa hidung mengandung eosinofil, kristal Charcot-Leyden, IgE antibodi jamur, limfosit $\mathrm{T}$ helper, dan sel antigen penyaji. ${ }^{7,8}$ Proses inflamasi pada RSK alergi jamur didominasi oleh sel $\mathrm{Th}_{2}$, dimana $\mathrm{Th}_{2}$ akan merangsang sel B dan mengaktivasi eosinofil serta meningkatkan jumlah eosinofil dengan meningkatkan ekspresi vascular cell adhesion molecule 1 (VCAM-1). Eosinofil yang teraktivasi akan mengalami degranulasi dan mengeluarkan mediator inflamasi, sehingga terjadi kerusakan mukosa. ${ }^{9-11}$

Belum banyak data penelitian tentang korelasi dan peran kadar IgE Aspergillus fumigatus di mukosa sinus maksila dan darah penderita RSK jamur. Penelitian ini dilakukan untuk mendapatkan tambahan pengetahuan yang dapat dimanfaatkan untuk mempermudah menegakkan diagnosis dan sebagai dasar pertimbangan untuk pemberian terapi penderita RSK akibat jamur, terutama jamur Aspergillus fumigatus di masa yang akan datang, serta memberikan data dasar bagi penelitian selanjutnya.

\section{METODE}

Penelitian ini merupakan penelitian analitik observasional dengan pendekatan cross sectional untuk mengetahui kesesuaian antara kadar $\operatorname{IgE}$ jaringan sinus dan darah pada penderita rinosinusitis maksila kronik jamur di Rumah Sakit dr. Saiful Anwar, Malang. Penelitian ini telah lolos uji ethic dan dilakukan pada bulan Januari-Oktober 2017. Pengambilan sampel pada penelitian ini menggunakan teknik consecutive sampling. Sampel penelitian adalah penderita rinosinusitis maksila kronik jamur dengan atau tanpa polip hidung yang datang berobat ke Poliklinik THT-KL Rumah Sakit dr. Saiful
Anwar, Malang, dan memenuhi kriteria inklusi dan eksklusi. Kriteria inklusi pada penelitian ini adalah penderita berusia lebih dari atau sama dengan 18 tahun saat dilakukannya penelitian yang menjalani pengobatan dengan punksi fossa kanina atau Caldwell Luc, dan pada pemeriksaan PCR didapatkan jamur Aspergillus fumigatus, dan penderita bersedia untuk ikut serta dalam penelitian dengan menandatangani pernyataan bersedia ikut serta dalam penelitian setelah mendapatkan penjelasan. Kriteria eksklusi adalah bila saat diagnosis ditegakkan sedang menjalani pengobatan dengan anti jamur baik sistemik maupun topikal selama $\geq 4$ minggu, atau dengan kortikosteroid sistemik selama $\geq 7$ hari dengan dosis setara metilprednisolon 40mg/ hari, atau kortikosteroid topikal selama $\geq 1$ bulan dengan dosis setara flutikason propionat $400 \mathrm{mcg} / \mathrm{hari}$.

Penderita rinosinusitis maksila kronik yang memenuhi kriteria inklusi dan eksklusi serta bersedia mengikuti penelitian, dilakukan pengambilan darah sebanyak $3 \mathrm{~mL}$ untuk pemeriksaan Enzyme-Linked Immunosorbent Assay (ELISA) IgE Aspergillus fumigatus dan disimpan dalam tabung vacutainer dengan ethylenediaminetetraacetic acid (EDTA). Penderita kemudian menjalani pembedahan dengan antrostomi anterior (punksi fossa kanina atau Caldwell Luc) yang dapat dilakukan dengan pembiusan umum maupun lokal oleh Dokter Supervisor Divisi Rinologi Departemen Ilmu Kesehatan THT-KL Rumah Sakit dr. Saiful Anwar. Pada pembedahan tersebut dilakukan pengambilan spesimen jaringan mukosa sinus maksila, kemudian disimpan dalam wadah steril dan selama transpor spesimen dengan menggunakan kotak pendingin yang selanjutnya akan dilakukan pemeriksaan ELISA IgE Aspergillus fumigatus. Penderita akan ditetapkan menjadi subjek penelitian setelah spesimen yang diambil dengan pembedahan diperiksa untuk identifikasi jamur Aspergillus fumigatus dengan PCR. Pemeriksaan PCR menggunakan instrumen Jena Bioscience ${ }^{\circledR}$ 
DNA Preparation Kit, Intron Maxime $\mathbb{}$ PCR Premix (master mix), DNA marker, $I D T \AA$ Primer DNA. Pemeriksaan PCR dan ELISA dilakukan di Laboratorium Ilmu Faal Fakultas Kedokteran Universitas Brawijaya, Malang. Penderita yang tidak memenuhi kriteria inklusi akan dieksklusikan dan tetap mendapat penanganan sesuai dengan panduan praktek klinis yang berlaku.

Semua data yang diperoleh akan diolah menggunakan program Statistical Package for the Social Sciences (SPSS) 23.0.0. Kadar rata-rata IgE Aspergillus fumigatus dalam jaringan sinus maupun darah akan dianalisis secara statistik deskriptif, dan hasil akan disajikan dalam bentuk tabel frekuensi distribusi. Data kesesuaian antara peningkatan kadar IgE Aspergillus fumigatus dari jaringan mukosa sinus maksila dengan darah, pertama dilakukan uji normalitas untuk mengetahui apakah data tersebut berdistribusi normal dengan menggunakan uji Shapiro Wilk, dilanjutkan dengan analisa menggunakan uji T berpasangan jika memenuhi distribusi normal. Jika tidak memenuhi distribusi normal, maka akan digunakan tes alternatifnya yaitu uji Wilcoxon. Perbedaan dikatakan bermakna apabila didapatkan $\mathrm{p}<0,05$.

\section{HASIL}

Pada periode penelitian, 24 penderita rinosinusitis maksilaris kronik dengan atau tanpa polip hidung menjalani pembedahan sinus maksila. Setelah dilakukan pemeriksaan PCR, didapatkan 13 penderita rinosinusitis maksilaris kronik jamur, yang memenuhi kriteria inklusi dan eksklusi untuk menjadi subjek penelitian. Identifikasi jamur merupakan proses penting, namun sulit dilakukan karena berbagai keterbatasan dari pemeriksaan penunjang yang tersedia. Meskipun PCR termasuk kategori mahal dan sulit untuk dilakukan, merupakan pemeriksaan yang memiliki sensitivitas dan spesifisitas paling tinggi dibandingkan pemeriksaan lain dalam membantu identifikasi jamur. Pada penelitian ini, spesimen mukosa sinus maksila diperiksa dengan PCR diperoleh hasil positif Aspergillus fumigatus.

Dalam penelitian ini didapatkan rerata IgE Aspergillus fumigatus mukosa sinus maksila adalah $1,112 \pm 0,883 \mathrm{kU} / \mathrm{mL}$ dengan rentang nilai 0,01 sampai 2,80 , sedangkan pada darah $1,041 \pm 0,876 \mathrm{kU} / \mathrm{mL}$ dengan rentang nilai 0,01 sampai 2,64 . Data $\mathrm{IgE}$ Aspergillus fumigatus yang telah didapatkan kemudian dilanjutkan uji normalitas dengan uji Shapiro Wilk didapatkan data IgE Aspergillus fumigatus mukosa sinus maksila memiliki distribusi normal $(\mathrm{p}=0,107)$ dan IgE Aspergillus fumigatus darah tidak memiliki distribusi normal $(\mathrm{p}=0,032)$. Kemudian dilakukan transformasi data untuk IgE Aspergillus fumigatus darah, tetapi tetap didapatkan distribusi yang tidak normal. Selanjutnya karena variabel numerik dapat dilakukan uji $\mathrm{T}$ berpasangan untuk mengetahui kesesuaian antara IgE Aspergillus fumigatus mukosa dengan darah. Dengan didapatkan hasil $(\mathrm{p}=0,852)$ yang menetapkan bahwa kadar IgE Aspergillus fumigatus darah dapat menggambarkan kadar IgE Aspergillus fumigatus pada mukosa sinus paranasal. Hal ini tercantum pada tabel 1 .

Neutrofil dan eosinofil merupakan mediator inflamasi pada RSK jamur yang berhubungan dengan IgE Aspergillus fumigatus. Pemeriksaan hitung sel neutrofil dan eosinofil dilakukan dengan pemeriksaan flowcytometry terhadap spesimen darah dan jaringan mukosa sinus maksila seperti yang tercantum pada tabel 2. Didapatkan rerata neutrofil mukosa 4,28 $\pm 2,04 \%$ dan eosinofil $3,91 \pm 1,92 \%$, sementara rerata neutrofil darah $49,41 \pm 13,98 \%$ dan eosinofil $4,88 \pm 2,02 \%$. Berdasarkan data-data tersebut kemudian dilakukan perhitungan untuk mengetahui rasio neutrofil/eosinofil dan menetapkan respon inflamasi yang dominan. Respon inflamasi yang paling banyak ditemukan pada mukosa sinus maksila pada penelitian 
Tabel 1. Kadar dan kesesuaian antara IgE Aspergillus fumigatus di mukosa sinus maksila dengan darah

\begin{tabular}{lccccc}
\hline \multirow{2}{*}{ IgE Aspergillus fumigatus } & $\mathbf{n}$ & Rerata \pm SD & $\begin{array}{c}\text { Median } \\
\text { (min-maks) }\end{array}$ & $\begin{array}{c}\text { Uji } \\
\text { normalitas }\end{array}$ & $\mathbf{p}$ \\
\cline { 3 - 5 } & 13 & $\mathbf{( k U / m L )}$ & $\mathbf{( k U / m L )}$ & $\mathbf{p}$ & \\
\hline Mukosa & 13 & $1,041 \pm 0,883$ & $1,500(0,01-2,80)$ & 0,107 & \multirow{2}{*}{0,852} \\
\hline Darah & 13 & $1,460(0,01-2,64)$ & 0,032 & \\
\hline
\end{tabular}

Tabel 2. Distribusi sel neutrofil dan eosinofil mukosa sinus maksila dengan darah

\begin{tabular}{|c|c|c|c|c|}
\hline \multirow{3}{*}{ Spesimen } & \multirow{3}{*}{$\begin{array}{c}\text { Neutrofil (\%) } \\
\text { Rerata } \pm \text { SD } \\
\text { (Rentang nilai) } \\
\end{array}$} & \multirow{3}{*}{$\begin{array}{c}\text { Eosinofil (\%) } \\
\text { Rerata } \pm \text { SD } \\
\text { (Rentang nilai) } \\
\end{array}$} & \multirow{2}{*}{\multicolumn{2}{|c|}{ Inflamasi }} \\
\hline & & & & \\
\hline & & & Neutrofil & Eosinofil \\
\hline \multirow[t]{2}{*}{ Mukosa } & $4,28 \pm 2,04 \%$ & $3,91 \pm 1,92 \%$ & 1 & 12 \\
\hline & $(0,91-8,28)$ & $(0,28-7,34)$ & $(7,7 \%)$ & $(92,3 \%)$ \\
\hline \multirow[t]{2}{*}{ Darah } & $49,41+13,98)$ & $4,88 \pm 2,02 \%$ & 6 & 7 \\
\hline & $(18,8071,12)$ & $(2,34-7,85)$ & $(46,2 \%)$ & $(53,8 \%)$ \\
\hline
\end{tabular}

Tabel 3. Kesesuaian rasio sel neutrofil/eosinofil mukosa sinus maksila dengan darah

\begin{tabular}{|c|c|c|c|c|c|c|}
\hline \multirow{2}{*}{$\begin{array}{l}\text { Rasio neutrofil/ } \\
\text { eosinofil }\end{array}$} & \multirow[t]{2}{*}{$\mathbf{n}$} & \multirow{2}{*}{ Rerata \pm SD } & \multirow{2}{*}{$\begin{array}{c}\text { Median } \\
\text { (min-maks) }\end{array}$} & \multicolumn{2}{|c|}{$\begin{array}{c}\text { Uji } \\
\text { normalitas }\end{array}$} & \multirow[t]{2}{*}{ p } \\
\hline & & & & $\mathbf{p}$ & p* & \\
\hline Mukosa & 13 & $1,77 \pm 2,28$ & $\begin{array}{c}1,36 \\
(0,22-9,14)\end{array}$ & 0.000 & 0,306 & \multirow{2}{*}{0,000} \\
\hline Darah & 13 & $12,12 \pm 6,25$ & $\begin{array}{c}9,27 \\
(2,98-24,96)\end{array}$ & 0,527 & & \\
\hline
\end{tabular}

Keterangan * setelah transformasi data

Tabel 4. Hasil uji korelasi pearson antara kadar IgE Aspergillus fumigatus dengan rasio neutrofil/eosinofil mukosa sinus maksila dan darah

\begin{tabular}{lcc}
\hline Korelasi & p & R \\
\hline IgE Aspergillus fumigatus dengan RNE mukosa & 0,523 & 0,195 \\
\hline IgE Aspergillus fumigatus dengan RNE darah & 0,607 & 0,157 \\
\hline
\end{tabular}

ini adalah inflamasi eosinofilik, sebesar $(92,3 \%)$ subjek penelitian, dan pada darah diperoleh $(53,8 \%)$.

Rerata RNE mukosa $1,77 \pm 2,28$ dan rerata RNE darah $12,12 \pm 6,25$. Rasio neutrofil/eosinofil yang telah didapatkan kemudian dilanjutkan uji normalitas dengan uji Shapiro Wilk, untuk RNE mukosa dinyatakan memiliki distribusi tidak normal $(\mathrm{p}=0,000)$, sedangkan pada darah didapatkan distribusi normal $(p=0,527)$. Untuk RNE mukosa dilakukan transformasi data dan uji normalitas ulang didapatkan hasil $(\mathrm{p}=0,306)$. Selanjutnya karena data normal dan variabel numerik, dilakukan uji T berpasangan untuk mengetahui kesesuaian antara RNE mukosa dan darah sesuai yang tercantum pada tabel 3 . Didapatkan perbedaan RNE mukosa dengan darah yang berbeda bermakna $(p=0,000)$ yang menunjukkan bahwa respon inflamasi di darah tidak dapat menggambarkan respon inflamasi yang terjadi pada mukosa sinus paranasal.

Data kadar IgE Aspergillus fumigatus dan rasio neutrofil/eosinofil pada mukosa sinus maksila dan darah telah diketahui mempunyai distribusi normal. Uji korelasi yang dapat dilakukan terhadap IgE Aspergillus fumigatus 
dan rasio neutrofil/eosinofil adalah uji korelasi Pearson (tabel 4). Berdasarkan hasil uji korelasi didapatkan kadar IgE Aspergillus fumigatus dengan rasio neutrofil/eosinofil pada mukosa sinus maksila memiliki korelasi yang tidak bermakna $(\mathrm{p}=0,523)$, yang artinya peningkatan kadar IgE Aspergillus fumigatus mukosa sinus maksila tidak menyebabkan perubahan rasio neutrofil/eosinofil pada mukosa sinus maksila. Kadar IgE Aspergillus fumigatus darah dengan rasio neutrofil/ eosinofil pada darah tidak mempunyai korelasi yang bermakna $(p=0,607)$, artinya peningkatan kadar IgE Aspergillus fumigatus tidak menyebabkan perubahan rasio neutrofil/ eosinofil darah.

\section{DISKUSI}

Rinosinusitis kronik merupakan proses inflamasi mukosa hidung dan sinus paranasal dengan prevalensi yang tinggi. Untuk membantu penegakan diagnosis, dapat menggunakan berbagai macam panduan, salah satunya adalah EP ${ }^{3} \mathrm{OS} .{ }^{12}$ Panduan tersebut menggabungkan antara keluhan subjektif penderita dengan temuan klinis baik dari pemeriksaan fisik maupun pemeriksaan penunjang. ${ }^{12,13}$

Setelah diagnosis ditegakkan dan penderita mendapat tatalaksana sesuai dengan algoritma yang ada namun tidak teratasi, perlu dicurigai kemungkinan penyebab lain, yaitu infeksi jamur. Untuk membuktikannya dibutuhkan pemeriksaan lanjutan yang bersifat invasif, atau alternatif pemeriksaan dan harga yang mahal. Hal inilah yang sering menjadi kendala dalam penentuan penyebab RSK jamur. Maharani $\mathrm{dkk}^{2}$ melaporkan hanya sekitar $31 \%$ penderita RSK jamur menunjukkan pertumbuhan jamur pada media kultur, sedangkan pemeriksaan dengan PCR didapatkan hasil 100\%. Pemeriksaan lainnya untuk menentukan jamur sebagai alergen dapat dengan mengukur kadar IgE Aspergillus fumigatus. Pemeriksaan kadar
IgE Aspergillus fumigatus yang dikerjakan dalam penelitian ini masih sulit diterapkan di Indonesia karena kurangnya fasilitas yang mampu melakukan pemeriksaan tersebut, sementara hanya bisa dilakukan di rumah sakit besar dan laboratorium swasta tertentu. Pemeriksaan yang lebih sederhana melihat reaksi alergi terhadap jamur yaitu dengan skin prick test/tes cukit kulit, akan tetapi untuk evaluasi jamur di Indonesia sudah tidak dilakukan dengan pemeriksaan ini sebab pernah dilaporkan terjadi reaksi anafiktik. Oleh karena itu, diperlukan suatu modalitas baru yang lebih murah dan mudah dilakukan namun minimal invasif, karena keterlibatan jamur pada RSK pada tiga dekade terakhir semakin meningkat. ${ }^{12-14}$

Pemeriksaan kadar IgE Aspergillus fumigatus seperti yang dikerjakan dalam penelitian ini bisa digunakan sebagai alternatif pemeriksaan, karena pemeriksaan ini dapat dilakukan tanpa tindakan invasif, tetapi masih sulit diterapkan di Indonesia karena kurangnya fasilitas yang mampu melakukan pemeriksaan tersebut dan pemeriksaan ini masih tergolong mahal.

Spora jamur berukuran kecil dan mudah terbawa oleh angin, sehingga mudah ditemukan di manapun dan terhirup oleh manusia, dan selanjutnya dapat terjadi kolonilisasi pada mukosa hidung dan sinus paranasal. ${ }^{15}$ Tidak semua spesies jamur menyebabkan RSK karena jamur bersifat oportunis. Setelah dilakukan pembedahan terhadap 20 penderita rinosinusitis maksila kronik, didapatkan 13 penderita dan dilanjutkan dengan pemeriksaan PCR, untuk identifikasi Aspergillus fumigatus. Hasil tersebut sesuai dengan literatur yang menyatakan disebabkan oleh faktor geografis, tingkat kelembapan udara dan iklim..$^{5,10}$ Pada penelitian ini dilakukan pengambilan sampel langsung dari sinus maksila melalui antrostomi anterior agar dapat menghindari kontaminasi dari rongga hidung. 
Penentuan keterlibatan jamur menggunakan metode PCR yang merupakan metode paling sensitif yang tersedia saat ini (mencapai lebih dari 90\%), dibandingkan metode lain seperti hibridisasi (sensitivitas sekitar 77\%) dan kultur (sensitivitas sekitar $51 \%$ ). Kelemahan dari teknik ini adalah biaya pemeriksaan yang mahal, teknik pemeriksaan yang sulit, tidak semua laboratorium dapat melakukan, serta belum tersedia sistem pemeriksaan komersial untuk diagnosis (hanya tersedia untuk kepentingan klinis). Pengambilan sampel juga memiliki peran penting dalam diagnosis karena dapat terjadi kontaminasi.

Adanya infeksi jamur ditandai oleh respon IgE yang tinggi. Pada individu atopik, sumbatan saluran nafas oleh karena jamur terjadi akibat paparan spora jamur yang tinggi, mengakibatkan respon $\mathrm{Th}_{2}$ yang memediasi reaksi IgE dan eosinofil. $\mathrm{Th}_{2}$ mempunyai efek imunitas antibodi yang independen, dimana aktivasi makrofag diinduksi oleh IL-13 dan diperkuat oleh IL33 sehingga memiliki efek fungisida. ${ }^{16,17} \mathrm{Hal}$ ini tidak sesuai dengan penelitian ini dimana tidak terdapat korelasi bermakna antara kadar IgE Aspergillus fumigatus mukosa dengan RNE mukosa $(p=0,523)$. Pada darah juga tidak terdapat korelasi bermakna antara kadar $\mathrm{IgE}$ Aspergillus fumigatus dengan RNE darah $(\mathrm{p}=0,607)$. Peningkatan kadar IgE Aspergillus fumigatus akan menyebabkan nilai RNE turun dan bergeser ke arah inflamasi eosinofil. Pada penelitian ini, pada mukosa sinus maksila 5 subjek penelitian didapatkan hasil kadar IgE Aspergillus fumigatus negatif, 6 subjek penelitian kadar IgE Aspergillus fumigatus dalam posisi positif samar dan 2 subjek penelitian didapatkan kadar IgE Aspergillus fumigatus positif. Nilai rasio neutrofil/ eosinofil pada mukosa sinus maksila dan darah tidak berbeda bermakna, dimana pada penelitian ini yaitu $92,3 \%$ subjek penelitian mengalami inflamasi eosinofilik. ${ }^{18}$ Dikatakan oleh Takeno dkk, ${ }^{10}$ pada kondisi inflamasi dominan eosinofilik tidak saja terjadi pada
RSK jamur tetapi juga bisa disebabkan oleh superantigen dari Staphylococcus aureus, biofilm dari bakteri dan infeksi virus, dimana pada keadaan ini sel epitel dari sinus paranasal dapat berperan sebagai antigen-presenting cell (APC) dan memperkuat respons inflamasi pada tingkat jaringan lokal melalui imunitas bawaan. ${ }^{10}$

Mekanisme superantigen dari Staphylococcus aureus sebagai alergen adalah dengan adanya paparan Staphylococcus enterotoksin $B$ (SEB) intranasal yang berulang, akan terjadi aktivasi sel dendritik melalui Tolllike receptors (TLR)-2 yang mengakibatkan ekspresi domain musin imunoglobulin sel T, sehingga terjadi sekresi IL-2 dengan kadar yang tinggi dan merangsang sel T CD4+ menjadi sel $\mathrm{Th}_{2}$, yang akan meningkatkan IL2,IL-4 dan IL-5 tetapi menghambat sitokin T reg, IL-10 dan growth factor- $\beta 1$. Selanjutnya menginduksi respon IgE, sehingga jumlah IgE meningkat dan terjadi peningkatan mediator eosinofilik (eosinophilic cationic protein) secara sistemik maupun lokal melalui pelepasan histamin pada paparan ulang. Hal ini menunjukkan adanya aktivitas superantigen dari Staphylococcus aureus. ${ }^{19-21}$

Biofilm adalah salah satu faktor yang menunjukkan perbedaan antara infeksi akut dan kronik. Biofilm banyak ditemukan pada kondisi infeksi kronik, yaitu pada RSK dengan atau tanpa polip hidung. Adanya biofilm dari bakteri menyebabkan kerusakan mukosa hidung dan meningkatkan inflamasi sel pada jaringan. Biofilm dari Staphylococcus aureus akan mengakibatkan inflamasi dengan peningkatan NF-KB, IL8 , TNF- $\alpha$, dan MIP 3a (protein inflamasi makrofag), mengakibatkan berkurangnya peranan opsonisasi dan fagositosis, serta timbulnya kekebalan terhadap imunitas pejamu seluler maupun humoral. ${ }^{22}$

Penelitian lain oleh Matsuwaki $\mathrm{dkk}^{21}$ dan Shin Seung dkk ${ }^{23}$ menyatakan bahwa terdapat korelasi antara peningkatan kadar IgE Aspergillus fumigatus dengan inflamasi 
eosinofilik pada rinosinusitis jamur. Jamur di udara bebas akan terhirup oleh saluran nafas dan akan memproduksi sitokin yang penting, yang berkaitan dengan IgE yang termediasi oleh alergi dan tipe inflamasi eosinofilik dengan memproduksi berbagai macam lipid mediator, sitokin, kemokin, matriks ekstraseluler, dan faktor pertumbuhan serta sumber mayor dari mediator inflamasi kimia, seperti Granulocyte-macrophage colonystimulating factor (GM-CSF), Regulated upon Activation Normal T cell Expressed and Secreted (RANTES), eotaxin, IL-6, dan IL-8. Selain itu Ramadhan ${ }^{24}$ mengatakan bahwa peningkatan presensi dari eosinofil berhubungan dengan tidak aktifnya $\mathrm{Th}_{1}$ sebagai dasar respon imun. Respon $\mathrm{Th}_{1}$ pada polip hidung mengikuti regulasi dari spesifik TLR yang terlibat dalam respon imun. Sekret hidung merupakan garis pertama pertahanan mukosa. Sekret hidung terdiri dari sejumlah kecil sitokin dan berbagai mediator inflamasi yang diproduksi oleh epitel dan sel imunokompeten. Peptida ini terkait dengan regulasi dari inflamasi dan pertahanan imun. Eosinofil yang teraktivasi memproduksi bermacam-macam substansi vasoaktif, sitokin, faktor kemotaktik, leukotriens, major basic protein, eosinophilic cationic protein, dan eosinophilic peroxidase. Peningkatan konsentrasi eosinofil akan meningkatkan inflamasi yang terjadi. Selain itu ada IL-5 yang merupakan sitokin dari $\mathrm{Th}_{2}$ yang mempunyai dferensiasi paling kuat, proliferasi, dan properti kemotaktik, serta rekruitmen ke jaringan dan pertahanan eosinofil. ${ }^{25}$

Pada penelitian ini, didapatkan 2 subjek penelitian memiliki hasil kadar IgE Aspergillus fumigatus positif pada mukosa dan 4 subjek penelitian memiliki hasil kadar IgE Aspergillus fumigatus positif pada darah. Menurut kriteria Bent dan Kuhn untuk menegakkan diagnosis rinosinusitis alergi jamur harus memenuhi seluruh kriteria mayor dan sebagian kriteria minor. Pada subjek penelitian dengan hasil positif pada kadar IgE Aspergillus fumigatus hanya memenuhi sebagian dari kriteria mayor yang sudah ditetapkan yaitu hipersensitifitas tipe 1 dan terdapat polip hidung. Untuk kriteria minor yang terpenuhi hanya terdapat asma, kelainan unilateral, dan terjadinya serum eosinofilia. Dapat disimpulkan bahwa seluruh subjek penelitian tidak terjadi reaksi alergi terhadap Aspergillus fumigatus, melainkan Aspergillus fumigatus yang terdeteksi hanya berperan sebagai komensal. ${ }^{26}$

Jamur termasuk mikroorganisme yang secara alamiah terdapat di tubuh manusia disebut flora normal atau mikrobiota. ${ }^{27}$ Faktor-faktor yang memengaruhi densitas dan penyebaran flora normal adalah kondisi lokal seperti $\mathrm{pH}$, temperatur, oksigen, air, ketersediaan pemenuhan nutrisi serta faktor lainnya, seperti peristalsis usus, saliva, sekresi lisozim, dan immunoglobulin. Mikroflora pada tubuh berdasarkan bentuk dan sifat kehadirannya dapat digolongkan menjadi dua, yaitu: 1) Mikroorganisme tetap/normal (resident flora/indigenous) yaitu mikroorganisme jenis tertentu yang biasanya ditemukan pada bagian tubuh tertentu, dan pada usia tertentu. Keberadaan mikroorganismenya akan selalu tetap, baik jenis ataupun jumlahnya, jika ada perubahan akan kembali seperti semula. Flora normal/ tetap yang terdapat pada tubuh merupakan organisme komensal. Flora normal yang lainnya bersifat mutualisme. Flora normal ini akan mendapatkan makanan dari sekresi dan produk-produk buangan tubuh manusia, dan tubuh memperoleh vitamin atau zat hasil sintesis dari flora normal. Mikroorganisme ini umumnya dapat lebih bertahan pada kondisi buruk dari lingkungannya. Contohnya: Streptococcus viridans, S. faecalis, Pityrosporum ovale, Candida albicans. 2) Mikroorganisme sementara (transient flora) yaitu mikroorganisme non patogen atau potensial patogen yang berada di kulit dan selaput lendir/mukosa selama kurun waktu beberapa jam, hari, atau minggu. Keberadaan mikroorganisme ini ada secara tiba-tiba (tidak tetap), dapat disebabkan oleh 
pengaruh lingkungan, tidak menimbulkan penyakit dan tidak menetap. Flora sementara biasanya sedikit asalkan flora tetap masih utuh; jika flora tetap berubah, maka flora sementara akan melakukan kolonisasi, berbiak dan menimbulkan penyakit. ${ }^{27}$

Berdasarkan hasil pada penelitian ini dapat disimpulkan bahwa semua subjek penelitian dapat dievaluasi kadar IgE Aspergillus fumigatus. Berdasarkan kadar tersebut peran Aspergillus fumigatus sebagai alergen tidak terbukti berkaitan dengan patofisiologi Allergic fungal rhinosinusitis, dan cenderung berperan sebagai komensal.

\section{DAFTAR PUSTAKA}

1. Eloy JA, Govindaraj S. Microbiology and immunology of rhinosinusitis. In: Thaler ER, Kennedy DW, editors. Rhinosinusitis a guide to diagnosis and management. New york: Springer; 2008. p.17-26.

2. Maharani I, Suheryanto R, Retnoningsih E. Airborne fungi in chronic rhinosinusitis patiens maxillary sinus lavage at Dr. Saiful Anwar Hospital Malang. Bali Medical Journal. 2016;5(2):18-24.

3. Pakdaman MN, Corry DB, Luong A. Fungi linking the pathophysiology of chronic rhinosinusitis with nasal polyps and allergic asthma. Immunol invest. 2011;40(7-8):76785.

4. Hashemian F, Bakhshaei M. The prevalence of positif fungal cultures in patients with chronic rhinosinusitis in a high altitude region of iran. Iranian J. of Otorhinolaryngol. 2012;24(66):29-33.

5. Chatterjee SS, Chakrabarti A. Epidemiology and medical mycology of fungal rhinosinusitis. Int J. Otorhinolaryngol Clinics. 2009; 1(1):1-13.

6. Badawy M.Sh, Badawy B.Sh, Yousef L.M, Sherief N.El. Evaluation of pulmonary fungal diseases in patients with fungal rhinosinusitis. egyp. Sos. of Chest Dis and Tuberculosis. 2013;62(3):493-500.

7. Upchurch K, Oh S, Joo H. Dectin-1 in the control pf th2-type $t$ cell responses. Receptor Clin Invest. 2016;3(1):1094-7.
8. Abbas KA, Licthtman AH, Pillai S. Celluler and molecular immunology. $8^{\text {th }}$ ed. Philadhelpia: Saunders Elsevier, 2015. p.228-32.

9. Ishitoya J, Sakuma Y, Tsukua M. Eosinophillic chronic rhinosinusitis in japan. Allergology International. 2010; 59:239-45.

10. Takeno S, Hirakawa K, Ishino T. Pathological mechanism and clinical features of eosinophillic chronic rhinosinusitis in the japanese population. Allergology International. 2010; 59(3):247-56.

11. Meltzer EO, Hamilos DL. Rhinosinusitis diagnosis and management for the clinician: a synopsis of recent consensus guidelines. Mayo Clinic Proceedings. 2011;86(5):42743.

12. Fokken WJ, Lund VJ, Mullol J, Bachert C, Cohen N, Cobo R, et al. European position paper on rhinosinusitis and nasal polyps. Rhinology. 2012; 50(1):1-12.

13. Adelson R, Marple B, Ryan M. Fungal rhinosinusitis. In: Johnson JT, Bailey JB, editors. Head and Neck SurgeryOtolaryngology. Baltimore: Lippincott Williams \& Wilkins; 2014. p.557-72.

14. Shetty A, Chavan K. Microbiology in invasive fungal sinusitis. In: Mankekar G, editors. Invasive fungal rhinosinusitis. New Delhi: Springer; 2014. p.39-50.

15. McCaffery. Diagnosis of fungal sinusitis. In: McCaffery T, editors. Rhinologic diagnosis and treatment. New York Stuttgart: Thieme; 1997. p.317-33.

16. Crameri R, Blaser K. Allergy and immunity to fungal infections and colonization. Infection and Immunity. 2002; 19(1):151-7.

17. Wuthrich M, Deepe GS, Klein B. Adaptive immunity to fungi. Annual review of Immunology. 2012; 30:115-48.

18. Wise SK, Ghegan MD, Gorham E, Schlosser RJ. Socioeconomic factors in the diagnosis of allergic fungal rhinosinusitis. Otolaryngology-Head and Neck Surgery. 2008; 138(1):38-42.

19. Zhang N, P Gevaert, T Van Zele, C. PerezNovo, J. Patou, G. Holtappels, et.al. An update on the impact of staphylococcus aureus enterotoxins in chronic sinusitis with nasal polyposis. Rhinology. 2005;43:162-8. 
20. Bachert C, Gevaert P, Zhang N, Zele V, Novo C. In: role of staphylococcal superantigens in airway disease. Chem Immunol Allergy. 2007; 93:214-36.

21. Matsuwaki Y, Uno K, Okushi T, Otori N, Moriyama $\mathrm{H}$. Total and antigen (fungi, mites and staphylococcal enterotoxins) specific iges in nasal polyps is related to local eosinophilic inflammation. Int Arch Allergy Immunol. 2013; 161(2):147-53.

22. Zernotti ME, Villegas A, Revol R, Cagnani B, Miranda A, Paredes ME, et al. Evidence of bacterial biofilms in nasal polyposis. J Investig Allergol Clin Immunol. 2010; 20(5):380-5.

23. Shin SH, Lee YH, Jeon CH. Protease dependent activation of nasal polyp epithelial cells by airborne fungi leads to migration of eosinophils and neutrophils. Acta OtoLaryngologica. 2005; 126(12):1286-94.
24. Ramadhan HH. Fungal rhinosinusitis. eMedicine Otolaryngology and Facial Plastic Surgery. 2009.

25. Peric A, Vojvodic D, Vukomanovic-Durdevic B, Baletic N. Eosinophilic inflamation in allergic rhinitis and nasal polyposis. J Arh Hig Rada Tokiskol. 2011; 62(4):341-8.

26. Kohler JR, Casadevall A, Perfect J. The spectrum of fungi that infects humans. Cold Spring Harb Perspect Med. 2015; 5(1):1-23

27. Pelczar, Michael J. Dasar-dasar mirobiologi. Jakarta: UI Press, 2009. p.549. 